\title{
Dimensional Changes of Luting Cements After Setting
}

\author{
Takahito KANIE, Shinichi NISHIOKA, Shigetaka NAGAOKA, Hong-Jih LIU \\ Masataka KAWAGOE, Hiroyuki ARIKAWA*, Kouichi FUJII*, Kazuhiko JYOSHIN* \\ and Katsuichiro INOUE* \\ Department of Operative Dentistry \\ *Department of Dental Materials Science Kagoshima University Dental School 1208-1, Usuki, Kagoshima \\ 890, Japan
}

Received on March 27, 1985

The dimensional changes of 4 types commercial luting cements after setting were examined in distilled water, using a developed thermal expansion testing apparatus. The measurements were carried out under three conditions: increasing temperature (from $37^{\circ} \mathrm{C}$ to $60^{\circ} \mathrm{C}$ ), decreasing temperature (from $37^{\circ} \mathrm{C}$ to $10^{\circ} \mathrm{C}$ ), and constant temperature $\left(37^{\circ} \mathrm{C}\right)$. The results indicated that: (1) the zinc phosphate cement possessed superior dimensional stability after setting ; (2) the variation values in dimension of Fuji Ionomer and CBA varied markedly with the specimen thickness tested; and (3) with Fuji Ionomer, this value also varied with the mixing proportion.

Key Words: Luting cements, Dimensional changes, Setting characteristics

\section{INTRODUCTION}

A variety of luting cements are widely used for bonding of restoratives. However, the magnitude of dimensional change of these cements during setting varies considerably from one product to another. ${ }^{1-4)}$

Therefore we investigated the effect of liquid/powder ratio (mixing proportion), temperature and specimen thickness on dimensional stability after setting.

\section{MATERIALS AND METHODS}

\section{Materials}

The materials used are listed in Table 1, together with mixing times and mixing proportions. All materials were mixed according to the manufacturer's recommendation at a temperature of $23 \pm 0.5^{\circ} \mathrm{C}$ and were transferred to the testing instrument 30 seconds after mixing.

2. Determination of setting time

The setting time of each material was determined using a Wilson rheometer according to the British Standards recommendations for composite filling material (BS 5199). ${ }^{5)}$

3. Preparation of test specimen for the dimensional stability test

Three test specimens, designated $0.9 \mathrm{~S}, 1.0 \mathrm{~S}$ and $1.1 \mathrm{~S}$, were prepared. The value represents the mixing ratio of powder added to a constant amount of liquid, thus the value, $1.0 \mathrm{~S}$, means that the test specimen was prepared according to the mixing proportion recom- 
mended by the manufacturer.

Each test specimen was prepared using a metal mould and two quartz glass plates having $5.6 \times 10^{-7} \mathrm{deg}^{-1}$ of coefficient of thermal expansion.

With respect to the test specimen $(0.5,1.0$ and $10.0 \mathrm{~mm}$ thickness $)$ with mixing proportion $1.0 \mathrm{~S}$, the dimensional change with specimen thickness, with the exception of zinc phosphate cements, was measured. For zinc phosphate cements, all test specimens except

Table 1 Materials used

\begin{tabular}{|c|c|c|c|c|c|c|c|}
\hline \multicolumn{2}{|l|}{ Material } & \multirow[t]{2}{*}{$\begin{array}{l}\text { Mixing time } \\
\quad(\mathrm{sec})\end{array}$} & \multirow[t]{2}{*}{$\begin{array}{c}\text { 0.9S } \\
\text { Powder(g) }\end{array}$} & \multirow[t]{2}{*}{$\begin{array}{c}1.0 \mathrm{~S} \\
\text { Powder(g) }\end{array}$} & \multicolumn{2}{|c|}{$\begin{array}{c}1.1 \mathrm{~S} \\
\text { Powder(g) }\end{array}$} & \multirow[t]{2}{*}{ Liquid(g) } \\
\hline Zinc Phosphate & & & & & & & \\
\hline Confit SMFP & $* 1$ & 60 & 1.26 & 1.40 & 1.54 & : & $0.5(\mathrm{ml})$ \\
\hline Elite 100 & $* 2$ & $"$ & 1.31 & 1.45 & 1.60 & $:$ & $"$ \\
\hline Crown, Bridge, Inlay & $* 2$ & $"$ & 1.35 & 1.50 & 1.65 & : & $"$ \\
\hline HY-Bond Zinc Phosphate & $* 3$ & $"$ & 1.35 & 1.50 & 1.65 & $:$ & $"$ \\
\hline \multicolumn{8}{|l|}{ Polycarboxylate } \\
\hline Unident SMFP & $*_{1}$ & 30 & 3.60 & 4.00 & 4.40 & : & 1.0 \\
\hline Carlon SMFP & $* 1$ & $"$ & 1.62 & 1.80 & 1.98 & : & $"$ \\
\hline Liv Cenera & $* 2$ & 40 & 1.80 & 2.00 & 2.20 & : & $"$ \\
\hline HY-Bond Polycarboxylate & $* 3$ & $"$ & 1.98 & 2.20 & 2.42 & $:$ & $"$ \\
\hline \multicolumn{8}{|l|}{ Glass Ionomer } \\
\hline Fuji Ionomer & $* 2$ & 40 & 1.26 & 1.40 & 1.54 & $:$ & $"$ \\
\hline HY-Bond Glass Ionomer & $* 3$ & 45 & 1.35 & 1.50 & 1.65 & : & $"$ \\
\hline \multicolumn{8}{|l|}{ Resin } \\
\hline CBA & $* 4$ & 30 & 1.80 & 2.00 & 2.20 & : & $"$ \\
\hline
\end{tabular}

*1 Sankin Industry, *2 GC Dental Industry, *3 Shofu Dental MFG and *4 Lee Pharmaceuticals

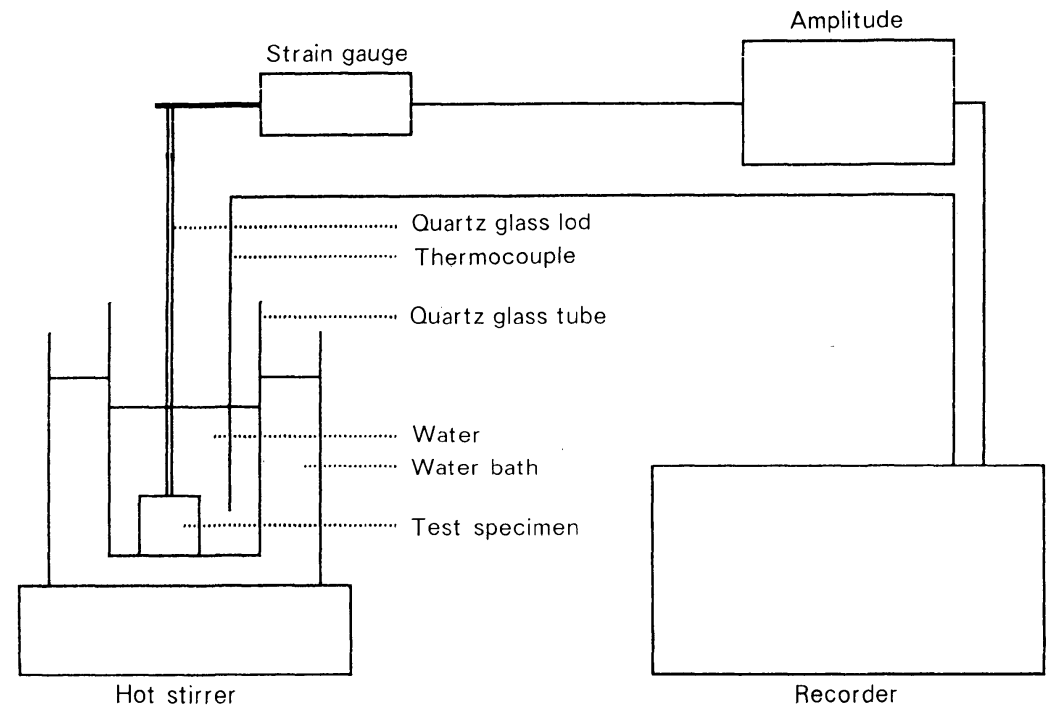

Figure 1 Schematic representation of apparatus used 
$10 \mathrm{~mm}$ thickness caused the separation of material from the quartz glass plate. Therefore, all tests were carried out using the test specimen of $10 \mathrm{~mm}$ thickness.

4. Measurement of the dimensional change

The schematic representation of the apparatus used is shown in Figure 1.

Dimensional changes with time; The test specimen was placed in the quartz tube with water maintained at $37 \pm 0.2^{\circ} \mathrm{C}$ and was measured for 30 minutes at $37 \pm 0.2^{\circ} \mathrm{C} 5$ minutes after setting.

Dimensional changes with temperature; The dimensional changes with increasing (from $37^{\circ} \mathrm{C}$ to $60^{\circ} \mathrm{C}$ ) and decreasing temperatures (from $37^{\circ} \mathrm{C}$ to $10^{\circ} \mathrm{C}$ ) were measured. The temperature was altered at a rate of $1^{\circ} \mathrm{C} / \mathrm{min}$.

\section{RESULTS AND DISCUSSION}

The setting times are shown in Table 2.

Zinc phosphate cements had the longest setting time compared with the other three types of cements. Glass ionomer and polycarboxylate cements showed similar values of setting time at a mixing proportion 1.0S. On the other hand, resin cement had the shortest setting time among cements used. All materials except Unident SMFP showed slight differences of setting time between $0.9 \mathrm{~S}$ and $1.1 \mathrm{~S}$ specimens tested. The magnitude of these differences increased in order of resin, polycarboxylate, glass ionomer and zinc phosphate cements. With Unident SMFP, no significant difference of setting time was noted among the three test specimens.

The dimensional changes with time are shown in Figure 2. All materials except Unident SMFP showed contraction. With glass ionomer cements, the dimensional changes at 30 minutes after the start of measurment were $-4.16 \mu \mathrm{m}$ for HY-Bond Glass Ionomer and $-2.34 \mu \mathrm{m}$ for Fuji Ionomer. These values were markedly large compared with the values of the other types of cements.

With materials excluding glass ionomer cements the variation values of dimensional change at 30 minutes were $2.52 \mu \mathrm{m}$ for polycarboxylate cements and $0.42 \mu \mathrm{m}$ for zinc phos-

Table 2 Setting times of cements used

\begin{tabular}{l|ccc}
\hline Material & $\begin{array}{c}0.9 \mathrm{~S} \\
(\mathrm{~min})\end{array}$ & $\begin{array}{c}1.0 \mathrm{~S} \\
(\mathrm{~min})\end{array}$ & $\frac{1.1 \mathrm{~S}}{(\mathrm{~min})}$ \\
\hline Confit SMFP & 7.3 & 6.0 & 5.4 \\
Elite 100 & 7.1 & 6.1 & 5.6 \\
Crown, Bridge, Inlay & 6.8 & 6.3 & 5.8 \\
HY-Bond Zinc Phosphate & 10.8 & 9.3 & 8.1 \\
\hline Unident SMFP & 5.3 & 5.6 & 5.5 \\
Carlon SMFP & 5.3 & 4.9 & 4.5 \\
Liv Cenera & 6.1 & 5.6 & 5.0 \\
HY-Bond Polycarboxylate & 5.0 & 4.9 & 4.4 \\
\hline Fuji Ionomer & 5.6 & 5.0 & 4.6 \\
HY-Bond Glass Ionomer & 6.4 & 5.7 & 4.8 \\
\hline CBA & 4.0 & 3.9 & 3.7 \\
\hline
\end{tabular}




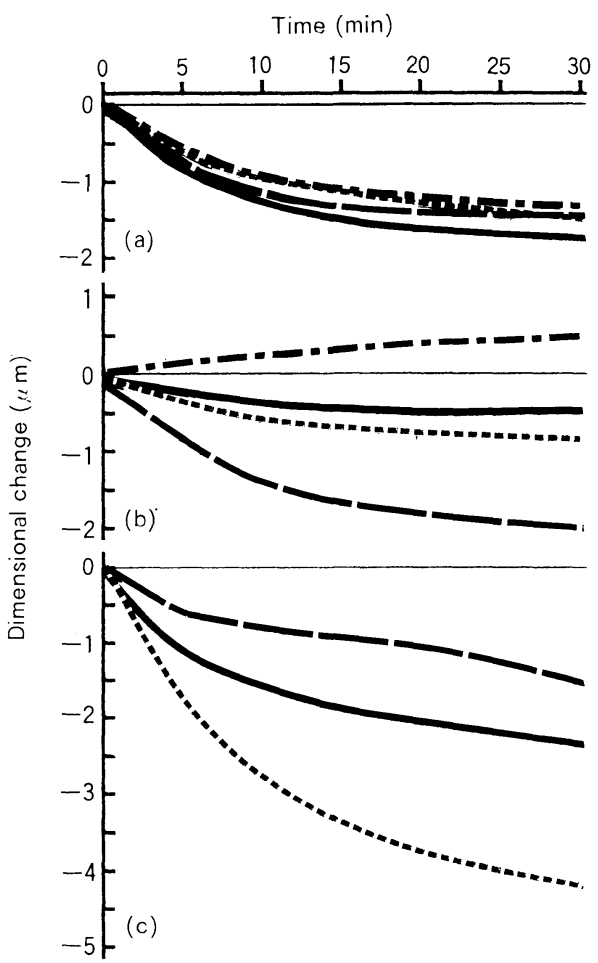

Figure 2 Dimensional changes with time of cements used at $37^{\circ} \mathrm{C}$. (a) Zinc phosphate cements (---.), Confit SMFP: - , Elite 100; -•-, Grown Bridge Inlay; - $\longrightarrow$ HYBond Zinc Phosphate), (b) Polycarboxylate cements (-•- Unident SMFP; — Carlon SMFP; - Liv Cenera; - HY-Bond Polycarboxylate), (c) Glass ionomer cements and resin cement (-, Fuji Ionomer; --.-., HY-Bond Glass Ionomer; - - CBA)

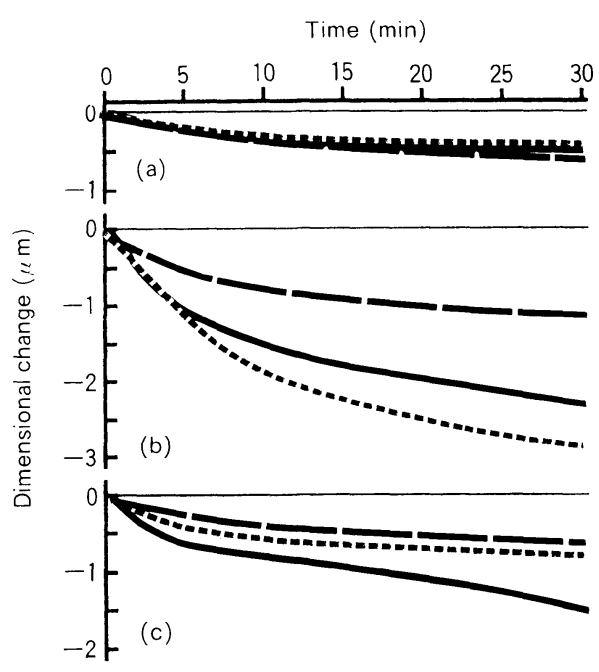

Figure 3 Dimensional changes with time for three specimen thicknesses at $37^{\circ} \mathrm{C}$.

(a) Carlon SMFP, (b) Fuji Ionomer,

(c) CBA, (-, $0.5 \mathrm{~mm}$; -..-. $1.0 \mathrm{~mm}$; -, $10.0 \mathrm{~mm}$ )

phate cements. These results indicate that the extent of dimensional change with time varies widely from one product to another, compared with other types of materials.

As shown in Figure 3, specimen thickness had no effect on dimensional change for Carlon SMFP. With CBA, the extent of dimensional change for the $0.5 \mathrm{~mm}$ thickness specimen at 30 minutes from the start of measurment was slightly larger than those for the other thickness specimens $(1.0$ and $10.0 \mathrm{~mm})$. On the other hand, with Fuji Ionomer, the extent of dimensional change with time varied markedly with the specimen thickness and the mixing proportion of specimen tested (Figure 4). These results indicate that the assessment of dimensional change for these cements in clinical application is difficult.

The dimensional changes with changes in temperature of the 4 types of cement are 
shown in Figure 5. All materials contracted as the temperature increased, except CBA. Particularly, polycarboxylate type cements showed a large contraction and had relatively

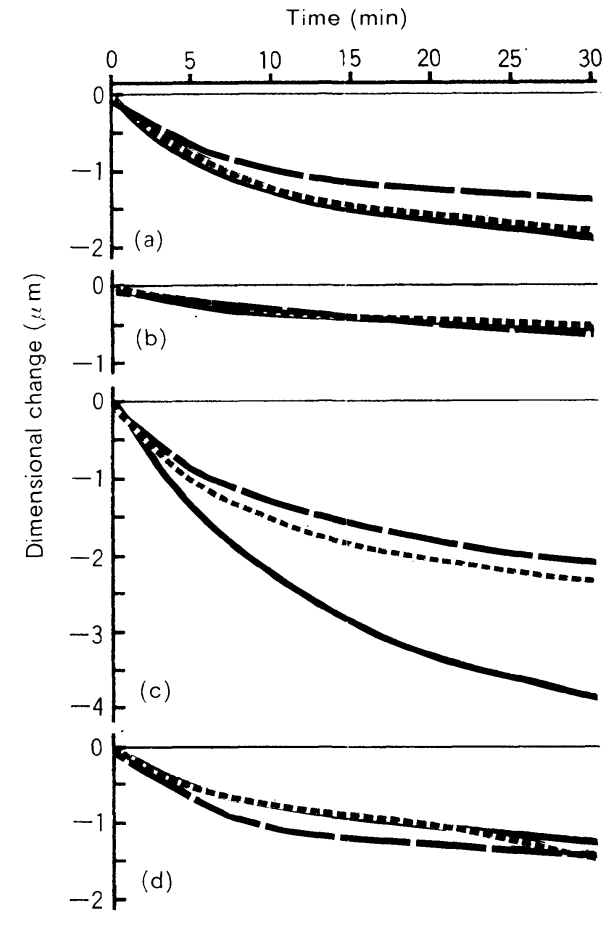

Figure 4 Dimensional changes with time for three mixing proportions at $37^{\circ} \mathrm{C}$. (a) HY-Bond Zinc, (b) Carlon SMFP, (c) Fuji Ionomer, (d) CBA, $(\longrightarrow, 0.9 \mathrm{~S} ; \cdots \cdots-1.0 \mathrm{~S} ;--$ $1.1 \mathrm{~S})$

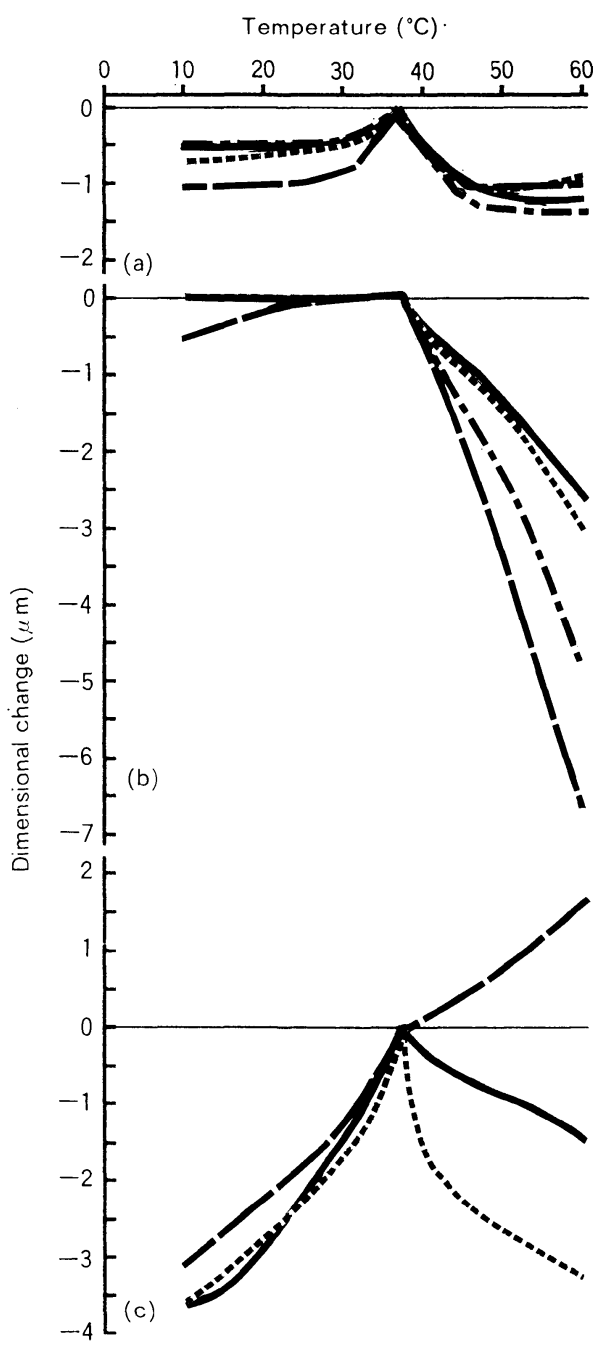

Figure 5 Dimensional changes with temperature of cements used. (a) Zinc phosphate cements (-----, Confit SMFP; - , Elite 100; -•-, Crown Bridge Inlay; -, HYBond Zinc Phosphate), (b) Polycarboxylate cements (-•-, Unident SMFP; —, Carlon SMFP; - Liv Cenera; -..-.-., HY-Bond Polycarboxylate), (c) Glass ionomer cements and resin cement (- Fuji Ionomer; -.---, HY-Bond Glass Ionomer; - - CBA) 
large variation values of the dimensional change among the materials.

With decreasing temperatures, all materials except Carlon SMFP, HY-Bond Polycarbo and Unident SMFP contracted, with glass ionomers and CBA showing the large contractions. These results demonstrate that zinc phosphate cements have the most excellent dimensional stability against the variation of temperature.

The effects of specimen thicknesses and mixing proportions on dimensional change with increasing temperatures are shown in Figures 6 and 7. With Carlon SMFP, Fuji Ionomer and CBA, the extent of dimensional change varied markedly with the specimen thickness, particularly, CBA showed a large variation value. This means that the magnitude of dimensional change of CBA is affected by specimen thickness and the setting reaction rate. $^{6)}$ Concerning the mixing proportion, all materials except CBA showed contraction, which became slightly small as the mixing proportion decreased. With Fuji Ionomer and HY-Bond Zinc Phosphate cements, this tendency was not noted as shown in Figure 4. For this reason, it is speculated that the dimensional change was caused by the contraction during setting, the thermal expansion with increasing temperature and the hygroscopic expansion in water. In the present investigation, however, it was difficult to clarify the effects of each parameter on dimensional change in detail.

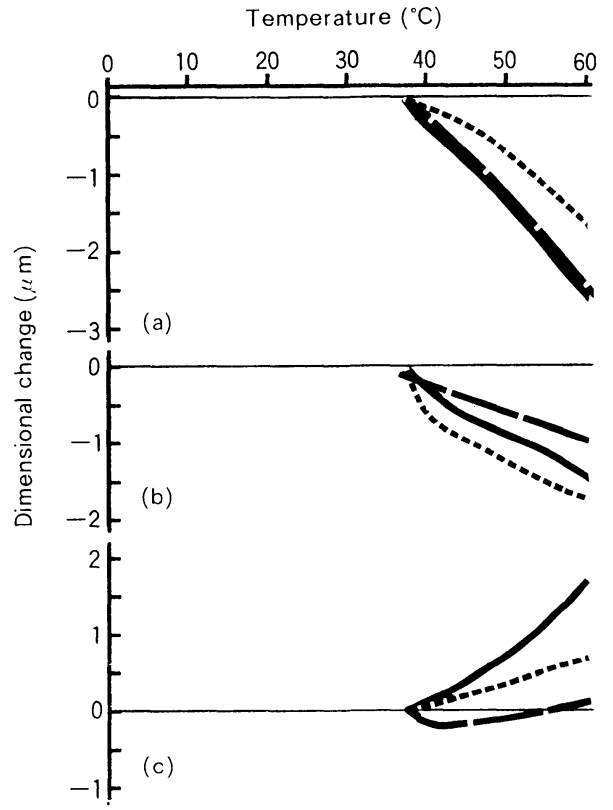

Figure 6 Dimensional changes with temperature for three specimen thicknesses.
(a) Carlon SMFP, (b) Fuji Ionomer,
(c) CBA, (-, $0.5 \mathrm{~mm} ; \cdot \cdots \cdots$, $1.0 \mathrm{~mm} ;--, 10.0 \mathrm{~mm})$

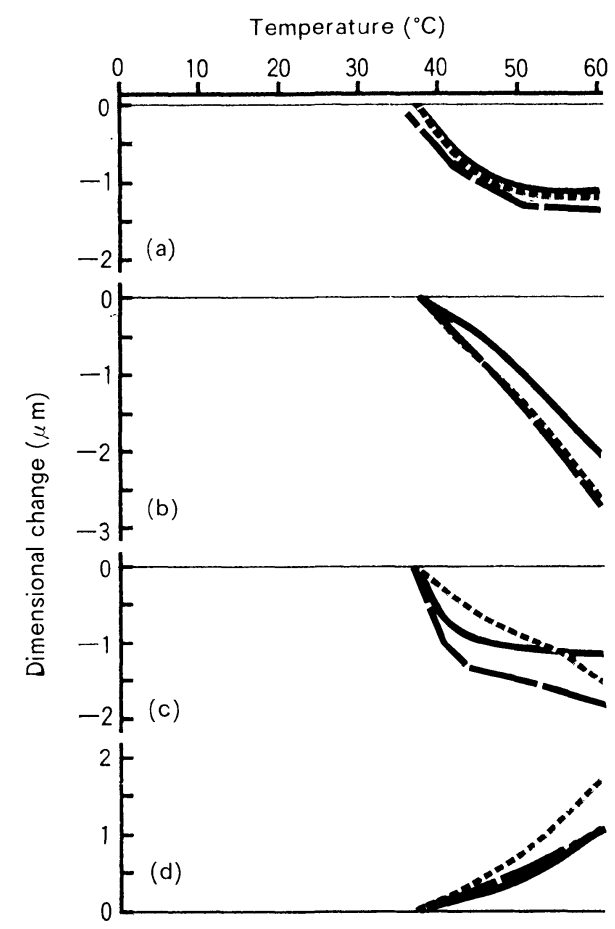

Figure 7 Dimensional changes with temperature for three mixing proportions. (a) HY-Bond Zinc, (b) Carlon SMFP, (c) Fuji Ionomer, (d) CBA, $(\longrightarrow, 0.9 \mathrm{~S} ; \cdots \cdot-\cdot$, 1.1 S) 
T. KANIE, S. NISHIOKA, S. NAGAOKA, H.-J. LIU, M. KAWAGOE, H. ARIKAWA, K. FUJII, K. JYOSHIN and K. INOUE

\section{CONCLUSIONS}

(1) Zinc phosphate cements (Confit SMFP, Elite 100, Crown Bridge Inlay and HY-Bond Zinc Phosphate) showed the superior dimensional stability in all experimental conditions employed.

(2) The extent of dimensional change of Fuji Ionomer was markedly varied with slight variation of mixing proportion.

(3) The variation values of dimensional change for Fuji Ionomer and CBA were markedly affected by thickness of test specimen.

\section{REFERENCE}

1) Joushin, K., Yamanaka, A., Moriwaki, Y., Tutumi, S. and Yamada, I.: Studies on the Zinc Phosphate Cement (II) On the Properties of Hydraulic Zinc Phosphate Cement after the Setting, J. Osaka. Univ. Dent. Soc., 8(1): 1-8, 1963. (in Japanese)

2) Nambu, T. and Tani, Y.: Study of Dimensional Changes of Dental Cements, J. Japan. Res. Soc. Dent. Mat. Appl., 36(4): 549-553, 1980. (in Japanese)

3) Yamada, S.: Fundamental Studies on Retention Force of Luting Cements, J. Kyushu. Dent. Soc., 35(1): 46-57, 1981. (in Japanese)

4) Hirano, Y.: Study on the Characteristic Changes in Glass Ionomer Cement for Luting, in Relation to the Passage of Time, J. J. Dent. Mat., 2(6): 691-707, 1983. (in Japanese)

5) Plant, C.C., Jones, I.H. and Wilson, H.J.: Setting Characteristics of Lining and Cementing Materials, Brit. Dent. J., 133: 21-24, 1972.

6) Kanie, T., Nishioka, S., Liu, H., Onigahara, S., Nagaoka, S., Kawagoe, M. and Inoue, K.: Studies on Dental Cements Part 1 Rheological Properties of Luting Cements during Setting, Japan. J. Concerv. Dent., 26(2): 143-152, 1983. (in Japanese) 
討を行った。

その結果によれば,いずれの材料にも時間一温度換算 則が適用でき，重福合わせの良好な合成曲線を作製する ことができた。パラフィンに，カルナウバワックスを添 加した場合, 高温側での応力緩和が著しく抑制されるこ
とがわかった。パラフィンにみつろうを添加すると，低 温側の弾性率が低下するととがわかった。またダンマル は混合物の応力緩和挙動にほとんど影響を与えないとと が明らかになった。

\section{溶融 $\mathrm{Ni}$ 基合金中の酸素の電気化学的測定 \\ 一添加元素としての $\mathrm{Cu}$ および $\mathrm{Cr}$ の影響一}

若狭邦男, 山木昌雄

\section{広島大学霜学部菌科理工学講座}

溶融 2 元系 $\mathrm{Ni}$ 基合金の酸素濃度を固体電解質を用い た電気化学的方法により評佂した。そのセルは， $\mathrm{Pt} \mid \mathrm{Mo}$ $+\mathrm{MoO}_{2}\left|\mathrm{ZrO}_{2}(\mathrm{MgO})\right| \underline{O}$ (液体) $\mid \mathrm{Mo}$ である。熱起電力 (EMF) 加ら決定する酸素活性は純 $\mathrm{Ni}$ に Cu を添加し た時增加した。すなわち, 酸素濃度は, その添加量が 1 $\mathrm{wt} \%$ 以上 $30 \mathrm{wt} \%$ までの時, 純 $\mathrm{Ni}$ での值よりも大きく
なった。 2 元系 $\mathrm{Ni}-\mathrm{Cr}$ 合金では， $5 ， 7$ および 10 wt\%

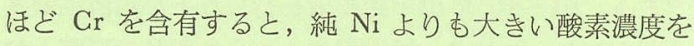
示すように思われ， 15 および 20 wt $\%$ Cr の添加によっ て, 純 $\mathrm{Ni}$ よりもより低い酸素濃度を呈するあのと推測 できる。

\section{機能性モノマーの歯科的応用（その9）}

各種 succinoxy methachylate の合成と無処理および酸処理歯質への接着性

福島忠男, 川口稔, 井上勇介, 宮崎光治, 堀部 隆

\section{福岡歯科大学 歯科理工学講座}

レジンの歯質への接着性を改善するために， succinoxyethyl methacrylate (2SEM) 飞各種蹯水基を導入した 新しい succinoxy methacrylate (sSPrM, SPPM, Bis-SGMA) と 2SEM の 4 種を合成し，柬質への接着性と構 造との関係を検討した。合成モノマーと BGDMA から 調製した各種 bonding agent を無処理（最終研摩：サ ンドペーパー\#600) と酸処理（37\%リン酸，1 分間処 理）牛歯エナメルおよびデンチンに薄く塗布し，その上 から即重レジンを填入して作製した接着試料について,
室温に10分間放置後（Dry：無処理），水中浸漬 1 日後 (Wet：無処理と酸処理)に引張り接着試験を行った。無 処理エナメルおよびデンチンへの接着性が Dry で最む 優れていたのは，それぞれ Bis-SGMA (50 mol\%) と2 SEM (55 65 mol\%) であった。Wet では SPPM (40 mol\%) と $2 \mathrm{SEM}(55 \sim 65 \mathrm{~mol} \%)$ であった。酸処理工 ナメルおよびデンチンへの接着力が最も優れていたの は，それぞれ SPPM (40 mol\%) と Bis-SGMA (15〜25 mol\%) であった。

\section{合着用セメントの硬化後の寸法変化}

蟹江隆人，西岡慎一，長岡成孝，劉 宏志，川越昌宜，

有川裕之*, 藤井孝一*, 上新和彦*, 井上勝一郎*

鹿児島大学菡学部 画科保存学 (1) 講座

*鹿児島大学菌学部菌科理工学講座

現在，市販されている４種類の系の合着用セメントについて練和比および武料寸法を変えた場合，硬化後の寸 
法変化率に変化があるか否かを検討した。測定方法は次 の 3 通りとした。

(1) 一定温度 $\left(37 \pm 0.2^{\circ} \mathrm{C}\right)$ のあとで経時的寸法変化 の測定

(2) $37^{\circ} \mathrm{C}$ から $60^{\circ} \mathrm{C}$ までの昇温 ( $\left.1{ }^{\circ} \mathrm{C} / \mathrm{min}\right)$ にともなう 寸法変化の測定

(3) $37^{\circ} \mathrm{C}$ から $10^{\circ} \mathrm{C}$ まで降温 $\left(1{ }^{\circ} \mathrm{C} / \mathrm{min}\right)$ にともなう 寸法変化の測定

その結果, リン酸塩系セメントの寸法変化量は, 方法
(1) では, $-1.8 \sim-1.4 \mu \mathrm{m}$, 方法 (2) では, $-1.3 \sim-0.9$ $\mu \mathrm{m}$, 方法 (3) では, $-1.0 \sim-0.4 \mu \mathrm{m}$ となり, 用いられ た他の系のセメントと比較して最む小さかった。練和比 を変えた場合の寸法変化量はフジアイオノマーが他のセ メントに比べて大きく, 方法 (1) では, $-3.8 \sim-2.0 \mu \mathrm{m}$, 方法 (2)では, $-1.8 \sim-1.2 \mu \mathrm{m}$ であった。試験片の厚 さを変えた場合の寸法変化量は, 方法 (1)では, フジアイ オノマーが最む大きく，-2.9〜1.1 $\mu \mathrm{m}$ であり, 方法(2) では, CBA が最む大きく, 0.2 1.7 $\mu \mathrm{m}$ であった。

\section{口腔軟組織の粘弾性}

第 1 報 口腔軟組織の弾性率を決定する一方法

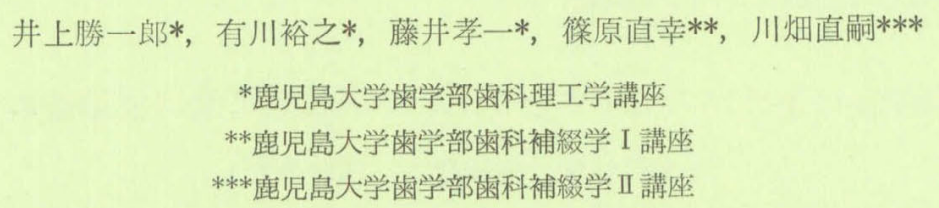

近年，義雨床支持組織に対する印象圧の影響に関する 報告がしばしばなされている。臨床的にみて好ましい印 象を採得するためには，印象材の物性はむとより，口腔 内組織の力学的性質も立分理解しておかなければならな 认。

本研究では, 口腔軟組織のレオロジカルな性質を把握 するための装置（エラストメータ）を試作し，口腔内で
あ充分使用できるととを確かめだ。本装置は, 感圧棒の 沈下量（圧接した場合に生じるくぼみの深さ）と感圧棒 に生じる力とから弾性率を決定する仕組になっている。 また本装置を用いて 2 人の患者に対して測定を行った結 果, 口腔内の測定部位によって見かけの硬さがかなり変 化するととがわかった。更に部位によっては，印象压に よる変形の可能性があるととも確誌した。

超微粒子フィラー配合コンポシットレシンの吸水量, 溶解量並びに 着色飞及ぼす研磨の影響

新谷英章, 佐藤尚毅, 行広 映, 佐藤淳子, 山根いぶみ, 香西淑子, 安道崇子, 甲斐真貴子, 林原久盛, 井上時雄

\section{広島大学 霜学部 \\ 歯科保存学第一講座}

超微粒子フィラー配合 composite resin 3 種類と従来 型 composite resin 1 種類を用い, 各レジンの圧接面, white-point 研磨面及び仕上げ研磨面を作製し，各研磨 面が吸水量，溶解量並びに着色に及ぼす影響を60日間に わたって検討した。

吸水量と溶解量は同じ傾向を示し，圧接面の吸水量が 大きく, white-point 研磨面，仕上げ研磨面の順に小さ くなった。四水量は水中浸漬初期では，研磨面と圧接面 間に有意差 $(\mathrm{p}<0.05)$ が認められたが, 時間の経過とと
あに差は減少した。MFR の Superlux, Silar の吸水量 が大きく，柾水性レジンの Microrest と従来型の P-10 が小さかった。

着色液として, タバコ煙液, コーヒ一液, 紅茶液, しょ う油液の 4 種を用い, 各研磨面の着色液浸漬前後の色差 值 $\Delta \mathrm{E}$ (Adams) を求めた。

$\Delta \mathrm{E}$ 值は white-point 研磨面のそれが最も高く, MFR 群の仕上げ研磨面は，圧接面と同程度もしくはそれより 低くなる傾向を示した。 